(c) American Dairy Science Association, 2007.

\title{
Treatment Practices and Quantification of Antimicrobial Drug Usage in Conventional and Organic Dairy Farms in Wisconsin
}

\author{
M. Pol and P. L. Ruegg ${ }^{1}$ \\ Department of Dairy Science, University of Wisconsin, Madison 53706
}

\section{ABSTRACT}

The objective of this study was to develop a method to quantify antimicrobial drug usage and treatment practices on conventional and organic dairy farms that had been recruited to represent a broad spectrum of potential exposure to antimicrobial drugs. Data on disease prevalence and treatment practices of organic $(\mathrm{n}=$ $20)$ and conventional $(n=20)$ farms were obtained during a farm visit using a survey instrument. A standardized estimate of antimicrobial drug usage was developed using a defined daily dose (DDD) of selected compounds. Density of antimicrobial drug usage was expressed as the number of DDD per adult cow per year. Differences in prevalence and management of selected diseases between conventional and organic farms were identified. The overall estimated prevalence of selected diseases was greater for conventional farms compared with organic farms. Organic farmers reported use of a variety of nonantimicrobial compounds for treatment and prevention of disease. Conventional farmers reported that penicillin was the compound most commonly used for dry cow therapy and cephapirin was most commonly used for treatment of clinical mastitis. On conventional farms, the estimated overall exposure to antimicrobial drugs was 5.43 DDD per cow per year composed of 3.58 and 1.85 DDD of intramammary and parenteral antimicrobial drugs, respectively. Of total intramammary antimicrobial drug usage, treatment of clinical mastitis contributed 2.02 DDD compared with 1.56 DDD attributed to the use of dry cow therapy. Of total parenteral treatments, the distribution of exposure was 0.52 (dry cow therapy), 1.43 (clinical mastitis treatment), 0.39 (treatment of foot disease), 0.14 (treatment of respiratory disease), and 0.32 (treatment of metritis) DDD. For treatments of foot infections ( 0.33 DDD), respiratory infections (0.07 DDD), and metritis (0.19 DDD), the mean density of ceftiofur usage was significantly greater compared with other compounds.

Received May 10, 2006.

Accepted August 3, 2006

${ }^{1}$ Corresponding author: plruegg@wisc.edu
Key words: dairy, antimicrobial drug, mastitis, treatment

\section{INTRODUCTION}

In modern dairy cattle operations, antimicrobial drugs are administered for both therapeutic and prophylactic purposes. Most antimicrobial drugs are used therapeutically for treatment of bacterial infections. Some antimicrobial drugs are used prophylactically to prevent disease in healthy animals during periods of increased susceptibility. The use of intramammary antibiotics at dry off is common in US dairy herds. Dry cow therapy (DCT) is typically administered as a treatment for existing subclinical mastitis infections and for prevention during the nonlactating period (McEwen and Fedorka-Cray, 2002; Aarestrup, 2004; Phillips et al., 2004).

In the United States, a limited number of antimicrobial drugs are marketed for intramammary treatment of mastitis. Antimicrobial classes include $\beta$-lactams (penicillin, cephapirin, ceftiofur, amoxicillin, hetacillin, and cloxacillin), macrolides (erythromycin), coumarines (novobiocin), and lincosamides (pirlimycin) (FDA-Center for Veterinary Medicine, 2005). A national survey of dairy herds (USDA/APHIS/VS/CEAH, 2005) reported that $>75 \%$ of farms used intramammary DCT in all cows. The same survey reported that cephapirin was the most used drug ( $42 \%$ of the cows), followed by penicillin/dihydrostreptomycin (32\%), and cloxacillin (13\%). Other drugs used for DCT included penicillin/novobiocin, novobiocin, penicillin, and erythromycin. A recent study of Wisconsin dairy herds participating in a milk quality improvement program reported that only $8 \%$ of farms were not using any form of DCT (Rodrigues et al., 2005).

Antimicrobial drugs are also used to treat other infectious diseases of dairy cows, including respiratory and uterine infections and infectious foot disease. Compounds commonly used to treat foot infections include sulfonamides, $\beta$-lactams, tetracyclines, and lincomycin (Merck Veterinary Manual, 2005). Various drugs are used for treatment of respiratory disease or metritis, including ceftiofur and other $\beta$-lactams, tylosin, tilmi- 
cosin, florfenicol, tetracyclines, and sulfadimethoxine (Merck Veterinary Manual, 2005).

The use of antimicrobial drugs in dairy farming is not without controversy and there is increasing interest in the use of organic production practices (Dhar and Foltz, 2003). In the United States, animals used for production of organic products may not receive hormones to promote growth or antibiotics for any reason. National organic standards prohibit the withholding of necessary treatment from a sick animal but the animal or its products may not be sold as organic if the animal ever received a prohibited compound, including antimicrobial drugs (USDA National Organic Program, 2002).

One study conducted before implementation of the current national organic standards demonstrated that a few antimicrobial drugs had been used by some organic farmers to treat selected diseases but not mastitis (Zwald et al., 2004). A more recent study confirmed that antimicrobial drugs are not used to treat mastitis that occurs on organic farms (Sato et al., 2005a). The objective of this study was to quantify antimicrobial drug usage and treatment practices on conventional and organic dairy farms that were recruited to represent a broad spectrum of potential exposure to antimicrobial drugs.

\section{MATERIALS AND METHODS}

\section{Herd Selection}

There is no central registry of organic farms (ORG); therefore, ORG farms were contacted using a list ( $\mathrm{n}=$ 77) of herds that had participated in a previous study (Zwald et al., 2004) or because they were known by extension agents to be certified ORG farms. All ORG farms were invited to participate in the study and all farms that met the inclusion criteria and were available for a farm visit during the study period were enrolled. Conventional farms (CON, $\mathrm{n}=20$ ) were recruited by extension agents familiar with the inclusion criteria. No attempt was made to randomly select the herds.

A separate part of this study (Pol and Ruegg, 2007) included collection of milk samples for microbiological analysis for determination of antimicrobial susceptibility. To increase the likelihood of recovering mastitis pathogens, enrollment criteria required herds to have a 6-mo average bulk tank somatic cell count (BTSCC) equal to or greater than 250,000 cells/mL. Additionally, to ensure at least one known exposure to antimicrobial drugs, CON farms were required to have used comprehensive antimicrobial DCT for at least 5 yr. Organic farms were required to be certified organic for at least $3 \mathrm{yr}$.

\section{Questionnaire}

Data on treatment practices were obtained using an 84-question survey instrument (available on request) administered by a single individual (MP) during a farm visit. The questions included inventory and expansion status (3 questions), production (4 questions), feed additives (3 questions), health records (5 questions), and prevalence and treatment practices for udder health and DCT (28 questions), clinical mastitis treatment (19 questions), respiratory disease in adult cows (7 questions), metritis (7 questions), and foot infections in cows (8 questions). The questionnaire was adapted from a previously published survey (Zwald et al., 2004). To aid in identification of antimicrobial drugs, the subject answering the survey was shown 8 laminated pages containing full-color pictures of commercially available veterinary antimicrobial drugs. The questionnaire took approximately 45 to $120 \mathrm{~min}$ to complete and was administered during the farm visit.

During the interview, the subjects were asked to estimate prevalence of selected diseases, the proportion of diseased animals that received treatment, and the disease-specific mortality. Case definitions for disease were farm specific and represented the farmers' perception of disease. Depending upon the question, the period for recall was either 2-mo or 1-yr periods before the visit. Estimates of disease prevalence (such as clinical mastitis, respiratory disease, metritis, and infectious foot disease) were based on recall in all farms except for 2 large farms in which estimates of prevalence included information obtained from computerized records.

\section{Estimation of Antimicrobial Drug Usage}

Exposure to Intramammary Dry Cow Products. Subjects reported the number of months and the proportion of animals treated with each intramammary product used for DCT during the previous $5 \mathrm{yr}$. The following formula was used to calculate the estimated antimicrobial drug exposure at farm level of each compound used for DCT:

$$
\mathrm{AMDCT}_{\mathrm{A}}=\left(4 \times \mathrm{DCT}_{\mathrm{A}}\right) \times \mathrm{CDM}_{\mathrm{A}} \times \mathrm{M}_{\mathrm{A}}
$$

where $\mathrm{AMDCT}_{\mathrm{A}}$ is the total antimicrobial drug " $\mathrm{A}$ " used for DCT per farm per year, $\mathrm{DCT}_{\mathrm{A}}$ is the dose (mg or IU) contained in one syringe of compound " $\mathrm{A}$ ", $\mathrm{CDM}_{\mathrm{A}}$ is the estimated number of cows dried per month with compound " $\mathrm{A}$ ", and $\mathrm{M}_{\mathrm{A}}$ is the estimated number of months that the compound " $\mathrm{A}$ " was used. For the analysis, the 5-yr average usage of each DCT antimicrobial drug was used and the assumption was made that DCT was administered to all 4 quarters of each cow once per year. 
Exposure to Other Antimicrobial Drugs Used for Treatment. Usage of antimicrobial drugs during the previous 2 yr for treatment of clinical mastitis, respiratory disease, metritis, and foot infections was estimated. The total dose (mg or IU) used on each farm was calculated based on the reported treatment protocol, proportion of use, and the reported disease prevalence. The following formula was used to calculate the estimated antimicrobial drug usage at the farm level of each compound utilized for each of the diseases studied:

$$
\mathrm{AMDZ}_{\mathrm{A}}=\mathrm{MG}_{\mathrm{A}} \times \mathrm{U}_{\mathrm{A}} \times \mathrm{F}_{\mathrm{A}} \times \mathrm{D}_{\mathrm{A}} \times \mathrm{YT}_{\mathrm{A}}
$$

where $\mathrm{AMDZ}_{\mathrm{A}}$ is the total antimicrobial " $\mathrm{A}$ " used for a specific disease at farm-level per year, $\mathrm{MG}_{\mathrm{A}}$ is the dose ( $\mathrm{mg}$ or IU) contained in a clinical mastitis syringe or milliliters of compound " $\mathrm{A}$ ", $\mathrm{U}_{\mathrm{A}}$ is the reported number of syringes or milliliters used in each treatment, $F_{A}$ is the reported times per day the compound was administered, $\mathrm{D}_{\mathrm{A}}$ is the reported number of days the compound was administered, and $\mathrm{YT}_{\mathrm{A}}$ is the reported number of animals that were treated with the compound "A" during a year.

\section{Calculation of the Defined Daily Dose}

To estimate antimicrobial drug exposure at the farm level, a veterinary drug defined daily dose (DDD) was characterized as the maximum dose that a standard animal $(\mathrm{BW}=680 \mathrm{~kg})$ would receive if it were treated following the FDA-approved label dosages. Defined daily doses were calculated using the following formula:

$$
\mathrm{DDD}_{\mathrm{A}}=\mathrm{MG}_{\mathrm{DDDA}} \times \mathrm{U}_{\mathrm{DDDA}} \times \mathrm{F}_{\mathrm{DDDA}}
$$

where $\mathrm{DDD}_{\mathrm{A}}$ is the DDD for antimicrobial " $\mathrm{A}$ ", $\mathrm{MG}_{\mathrm{DDDA}}$ is the dose ( $\mathrm{mg}$ or IU) contained in a milliliter or in an intramammary syringe of compound " $\mathrm{A}$ ", $\mathrm{U}_{\mathrm{DDDA}}$ is the number of milliliters used in each administration, and $\mathrm{F}_{\text {DDDA }}$ is the number of times per day the compound is administered. For each antimicrobial drug and for each route, a DDD was assigned based on the FDA Center for Veterinary Medicine Green Book approved label on doses and daily frequency of treatment (Table 1).

For each farm, the number of DDD used at the farm level was calculated by dividing the reported total dose (mg or IU) of each antimicrobial used per year by the DDD of that antimicrobial drug. To estimate the density of use of the drug, the number of DDD was divided by the total number of milking cows. Antimicrobial drug usage density was expressed as number of DDD per lactating cow per year.

\section{Statistical Analysis}

Survey data were entered into a spreadsheet and PROC FREQ (SAS Institute, 1999) was used to perform $\chi^{2}$ analysis to evaluate associations between herd type (CON vs. ORG) and selected management practices, prevalence of disease, or treatments. In each model, herd type formed the rows of the table and dichotomous definitions of the selected management practice formed the columns. Each disease was evaluated separately and the occurrence or absence of disease formed the columns. Standard plate count and BTSCC were categorized and formed columns for 2 separate models. The association between herd type and satisfaction with treatments was tested separately for products used for treatment of clinical mastitis or DCT. When expected values were less than 5 in more than $20 \%$ of the cells, the Fisher's exact test was used. Differences in normally distributed variables (animal inventory and milk yield) based on farm type (CON vs. ORG) were analyzed using PROC ANOVA of SAS (SAS Institute, 1999).

Differences in usage of antimicrobial compounds were estimated using the DDD and compared for selected diseases using PROC ANOVA. When the DDD was not normally distributed, a natural-log transformation was used to achieve normality. The number of doses of each compound was compared among herds that treated differing proportions of animals ( $<$ first quartile; interquartile range; third quartile of treatments). Only compounds used in $>5$ herds were analyzed. Pairwise comparisons were made using least significant difference with $\alpha=0.05$. Correlations were assessed using the CORR procedure of SAS (SAS Institute, 1999). In all instances, a $P$-value of $<0.05$ was considered for statistical significance.

\section{RESULTS}

\section{Herd Characteristics}

Dairy herds $(\mathrm{n}=40)$ were visited between June 2004 and July 2005. As expected, CON herds were larger (197 vs. 72 lactating cows, respectively) and produced more milk per cow per day (33 vs. $21 \mathrm{~kg}$, respectively) compared with ORG herds $(P<0.018)$. Herd type was associated with the percentage of adult cows that were born and raised on the farm (100\% for $10 \%$ and $60 \%$ of CON and ORG farms, respectively; 50 to $99 \%$ for $75 \%$ and $30 \%$ of CON and ORG farms, respectively; and $<50 \%$ for $>15 \%$ and $10 \%$ of CON and ORG herds, respectively; $P=0.002$ ).

In accordance with inclusion criteria for this study, there was no association between BTSCC $(P=0.83)$ or SPC $(P=0.33)$ and herd type. The BTSCC was between 200,000 and 299,000 cells/mL for $10 \mathrm{CON}$ and $12 \mathrm{ORG}$ 
Table 1. Defined daily doses (DDD) of selected antimicrobial drugs ${ }^{1}$

\begin{tabular}{|c|c|c|c|c|c|}
\hline Intended use and drug used & $\begin{array}{l}\text { Amount per } \\
\text { syringe or } \mathrm{mL}\end{array}$ & $\begin{array}{l}\text { Number of } \\
\text { syringes } \\
\text { or } \mathrm{mL}\end{array}$ & $\operatorname{Dose}^{2}$ & $\begin{array}{l}\text { Frequency, } \\
\text { times/day }\end{array}$ & DDD \\
\hline \multicolumn{6}{|l|}{ Intramammary dry cow therapy } \\
\hline Cloxacillin benzathine & $500 \mathrm{mg}$ & 4 & & 1 & $2,000 \mathrm{mg}$ \\
\hline Dihydrostreptomycin sulfate & $1,000 \mathrm{mg}$ & 4 & & 1 & $4,000 \mathrm{mg}$ \\
\hline Erythromycin & $600 \mathrm{mg}$ & 4 & & 1 & $2,400 \mathrm{mg}$ \\
\hline Novobiocin sodium & $400 \mathrm{mg}$ & 4 & & 1 & $1,600 \mathrm{mg}$ \\
\hline Amoxicillin trihydrate & $62.5 \mathrm{mg}$ & 1 & & 2 & $125 \mathrm{mg}$ \\
\hline Ampicillin & $62.5 \mathrm{mg}$ & 1 & & 1 & $62.5 \mathrm{mg}$ \\
\hline Ceftiofur & $125 \mathrm{mg}$ & 1 & & 1 & $125 \mathrm{mg}$ \\
\hline Cephapirin sodium & $200 \mathrm{mg}$ & 1 & & 2 & $400 \mathrm{mg}$ \\
\hline Cloxacillin sodium & $200 \mathrm{mg}$ & 1 & & 2 & $400 \mathrm{mg}$ \\
\hline Erythromycin & $300 \mathrm{mg}$ & 1 & & 2 & $600 \mathrm{mg}$ \\
\hline Penicillin G procaine & $600,000 \mathrm{IU}$ & 1 & & 2 & $1,200,000 \mathrm{IU}$ \\
\hline \multicolumn{6}{|l|}{ Parenteral treatments } \\
\hline Ceftiofur sodium & $50 \mathrm{mg}$ & & $2.2 \mathrm{mg} / \mathrm{kg}^{3}$ & 1 & $1,500 \mathrm{mg}$ \\
\hline Florfenicol & $300 \mathrm{mg}$ & & $20 \mathrm{mg} / \mathrm{kg}$ & 1 & $13,600 \mathrm{mg}$ \\
\hline Oxytetracycline dihydrate & $200 \mathrm{mg}$ & & $11 \mathrm{mg} / \mathrm{kg}^{3}$ & 1 & $7,500 \mathrm{mg}$ \\
\hline Penicillin & $300,000 \mathrm{IU}$ & & $1 \mathrm{~mL} / 45.4 \mathrm{~kg}^{3}$ & 1 & $4,500,000 \mathrm{IU}$ \\
\hline Sulfadimethoxine & $400 \mathrm{mg}$ & & $27.5 \mathrm{mg} / \mathrm{kg}^{3}$ & 1 & $18,750 \mathrm{mg}$ \\
\hline Florfenicol & $300 \mathrm{mg}$ & & $20 \mathrm{mg} / \mathrm{kg}$ & 1 & $13,600 \mathrm{mg}$ \\
\hline Tylosin & $200 \mathrm{mg}$ & & $17.6 \mathrm{mg} / \mathrm{kg}^{3}$ & 1 & $12,000 \mathrm{mg}$ \\
\hline
\end{tabular}

${ }^{1}$ Dosage obtained from Food and Drug Administration-Center of Veterinary Medicine, 2004.

${ }^{2} \mathrm{Cow}$ weight was assumed to be $680 \mathrm{~kg}$.

${ }^{3}$ Label doses were converted to metric units.

herds; between 300,000 and 399,000 cells $/ \mathrm{mL}$ for $6 \mathrm{CON}$ and 5 ORG herds; and above 400,000 cells $/ \mathrm{mL}$ for 4 CON and 3 ORG herds. The SPC was below $5,000 \mathrm{cfu} /$ $\mathrm{mL}$ for $13 \mathrm{CON}$ and 10 ORG herds and above 5,000 for $7 \mathrm{CON}$ and 10 ORG herds.

\section{Occurrence of Selected Diseases}

Almost every CON farmer reported the yearly occurrence of mastitis, foot infections, respiratory infections, and metritis (Table 2). Similarly, almost every ORG farmer reported the yearly occurrence of mastitis and metritis. However, fewer ORG farmers reported the occurrence of respiratory disease (20\% of herds) and foot infections $(60 \%$ of herds; $P<0.001)$ compared with CON farmers. The combined prevalence of selected diseases was greater for CON farms compared with ORG farms $(P<0.001)$. Conventional farmers reported a higher proportion of treatments of clinical mastitis and metritis $(P<0.001)$ but a similar proportion of treated cases of foot infection and respiratory disease $(P=0.17$; Table 2) compared with ORG farmers.

Table 2. Yearly frequency of selected diseases for conventional cows ( $\mathrm{n}=3,937 ; \mathrm{n}=20$ herds) and organic cows $(\mathrm{n}=1,449 ; \mathrm{n}=20$ herds)

\begin{tabular}{|c|c|c|c|c|c|c|}
\hline & \multicolumn{3}{|c|}{ Clinical mastitis } & \multicolumn{3}{|c|}{ Respiratory disease } \\
\hline Number of farms with reported cases (\%) & $20(100.0)$ & $20(100.0)$ & & $20(100.0)$ & $4(20.0)$ & $<0.001$ \\
\hline Range of yearly frequency ( $\%$ of total cows) & $4.0-156.0$ & $4.0-57.0$ & & $1.0-24.0$ & $0.0-10.0$ & \\
\hline \multirow[t]{2}{*}{ Clinical cases treated per year ( $\%$ of total cases) } & 94.0 & 71.0 & $<0.001$ & 99.0 & 92.0 & 0.17 \\
\hline & \multicolumn{3}{|c|}{ Metritis } & \multicolumn{3}{|c|}{ Foot infection } \\
\hline Number of farms with $r$ & $20(100.0)$ & $19(95.0)$ & 1.00 & $19(95.0)$ & $12(60.0)$ & 0.02 \\
\hline Number of reported cases per year (\% of total cows) & $605(15.3)$ & $136(9.3)$ & $<0.001$ & $779(19.7)$ & $357(24.6)$ & $<0.001$ \\
\hline Range of yearly frequency ( $\%$ of total cows) & $3.0-42.0$ & $0.0-23.0$ & NA & $0.0-111.0$ & $0.0-69.0$ & NA \\
\hline Clinical cases treated per year (\% of total cases) & 95.0 & 71.0 & $<0.001$ & 96.0 & 97.0 & 0.21 \\
\hline
\end{tabular}


Table 3. Descriptive statistics of estimated defined daily doses (DDD) per cow per year of antimicrobial drugs used at dry-off on conventional herds reporting use of each compound

\begin{tabular}{|c|c|c|c|c|c|c|}
\hline \multirow[b]{2}{*}{ Treatment } & \multirow{2}{*}{$\begin{array}{l}\text { Herds with } \\
\text { reported } \\
\text { use, }{ }^{1} \mathrm{n}\end{array}$} & \multirow[b]{2}{*}{$(\%)$} & \multicolumn{4}{|c|}{ DDD per cow per year ${ }^{2}$} \\
\hline & & & Mean $^{3}$ & $\mathrm{SE}$ & Minimum & Maximum \\
\hline \multicolumn{7}{|l|}{ Intramammary } \\
\hline Penicillin & 18 & $(90.0)$ & $0.62^{\mathrm{a}}$ & 0.08 & 0.03 & 1.00 \\
\hline Streptomycin & 18 & $(90.0)$ & $0.62^{\mathrm{a}}$ & 0.09 & 0.03 & 1.00 \\
\hline Cephapirin & 15 & $(75.0)$ & $0.55^{\mathrm{a}}$ & 0.08 & 0.03 & 1.00 \\
\hline Novobiocin & 3 & $(15.0)$ & 0.22 & 0.12 & 0.20 & 0.44 \\
\hline \multicolumn{7}{|l|}{ Parenteral } \\
\hline Penicillin & 5 & $(25.0)$ & 0.43 & 0.31 & 0.01 & 1.66 \\
\hline Tetracycline & 4 & $(20.0)$ & 0.37 & 0.32 & 0.01 & 1.33 \\
\hline Tylosin & 4 & $(20.0)$ & 0.13 & 0.13 & $<0.01$ & 0.53 \\
\hline
\end{tabular}

${ }^{a}$ Means of defined daily doses of intramammary compounds with same superscript did not differ significantly $(P=0.77)$.

${ }^{1}$ Farms could report the use of multiple products.

${ }^{2}$ For farms reporting usage.

${ }^{3}$ Comparison among means was done for compounds used in more than 5 herds.

\section{Mastitis Management}

The overall proportion of animals culled due to mastitis $(\mathrm{CON}=8.8 \%$ of total cows; $\mathrm{ORG}=8.9 \%)$ was not associated with herd type $(P=0.75)$. Detection of clinical mastitis and criteria used to decide if a cow was cured after treatment of clinical mastitis were associated with farm type $(P<0.02)$. Of CON farmers, 90\% reported that they identified mastitis based on observation of milk compared with only $45 \%$ of ORG farmers. Other nonspecified methods to detect clinical mastitis were used by 10 and $55 \%$ of CON and ORG herds, respectively. The assessment of cure after treatment of clinical mastitis was based on observation of normal milk for 75 and $20 \%$ of CON and ORG herds, respectively. Farm type was not associated with the decision to change parenteral products used to treat mastitis $(P=0.72)$, but was associated with the decision to change intramammary (IMM) products $(P<0.001)$. Of CON farmers, $80 \%$ reported that they frequently changed IMM products compared with only $15 \%$ of ORG farmers. The most common reason given for changing IMM products was veterinarian recommendation (35\% of CON farms). Other reasons cited were treatment failure (10\%) and cost (10\%). Only 1 farm reported IMM product rotation to avoid the development of antimicrobial resistance.

\section{$D C T$}

In accordance with the herd inclusion criteria, intramammary antimicrobial treatments were used in all quarters of all cows on all CON farms at dry-off. Most CON farms $(n=13)$ had used the same DCT product over the last $5 \mathrm{yr}$, but some rotated DCT products biannually $(\mathrm{n}=4)$ or annually $(\mathrm{n}=3)$. Reasons for changing
DCT products included recommendation of the veterinarian $(\mathrm{n}=4)$ or to avoid the development of antimicrobial resistance $(n=3)$. One ORG farm reported the use of antimicrobial drugs to treat a few (1\%) quarters at dry-off.

Penicillin and streptomycin were the most frequently used ( $\mathrm{n}=18$ farms; Table 3) compounds for DCT, and usage of these compounds was highly correlated $(\mathrm{r}=$ $0.99, P<0.001$ ) because a popular product contains both compounds. Density of cephapirin use was inversely correlated $(\mathrm{r}=-0.99, \mathrm{n}=13, P<0.001)$ with density of penicillin use. The use of cephapirin ( $\mathrm{n}=15$ farms) or novobiocin ( $\mathrm{n}=3$ farms) was reported by fewer farmers (Table 3). No differences were observed in the number of DDD reported used for penicillin, streptomycin, and cephapirin $(P=0.77)$. Nine CON farmers reported that they regularly used parenteral antimicrobial drugs at dry-off. Compounds used included penicillin, tetracycline, and tylosin (Table 3).

Half of the ORG farmers reported using nonantimicrobial products to improve udder health at dry-off. Ultrafiltered bovine whey products given by various routes (oral, intramuscular, and subcutaneous) were the most common (5 farms) treatment. Other products used by ORG farmers were vitamin supplements (3 farms; administered by oral or intramuscular routes), microbial supplements ( 2 farms; administered by intramammary infusion), vitamin C (2 farms; administered by intramammary infusion), aloe vera ( 2 farms; administered orally), homeopathy (1 farm), and intramammary infusion of olive oil ( 1 farm).

There was no significant difference in satisfaction with DCT based on herd type $(P=1.0)$. About $80 \%$ of the farmers were satisfied or very satisfied with the result of the treatment, and $20 \%$ were somewhat satisfied with DCT product. 
POL AND RUEGG

Table 4. Descriptive statistics of estimated defined daily doses (DDD) per cow per year of antimicrobial drugs used for treatment of clinical mastitis on conventional herds reporting use of each compound

\begin{tabular}{|c|c|c|c|c|c|c|c|}
\hline \multirow[b]{2}{*}{ Treatment } & \multirow{2}{*}{$\begin{array}{l}\text { Herds with } \\
\text { reported } \\
\text { use, }{ }^{1} \mathrm{n}\end{array}$} & \multirow[b]{2}{*}{$\%$} & \multicolumn{5}{|c|}{ DDD per cow per year ${ }^{2}$} \\
\hline & & & $\begin{array}{l}\text { Mean } \\
\text { Ln-DDD }^{3}\end{array}$ & Mean & SE & Minimum & Maximum \\
\hline \multicolumn{8}{|l|}{ Intramammary } \\
\hline Cephapirin & 18 & 90.0 & $-0.81^{\mathrm{a}}$ & 1.31 & 0.57 & 0.03 & 10.34 \\
\hline Pirlimycin & 15 & 75.0 & $-1.26^{\mathrm{a}}$ & 0.70 & 0.25 & 0.01 & 3.74 \\
\hline Amoxicillin & 8 & 40.0 & $-0.92^{\mathrm{a}}$ & 0.66 & 0.28 & 0.15 & 1.97 \\
\hline Cloxacillin & 2 & 10.0 & & 0.32 & 0.27 & 0.05 & 0.59 \\
\hline Erythromycin & 2 & 10.0 & & 0.08 & 0.08 & 0.00 & 0.16 \\
\hline \multicolumn{8}{|l|}{ Parenteral } \\
\hline Penicillin & 7 & 35.0 & $-1.84^{\mathrm{x}}$ & 0.68 & 0.51 & 0.02 & 3.74 \\
\hline Tetracycline & 7 & 35.0 & $-2.51^{x}$ & 0.12 & 0.05 & 0.02 & 0.40 \\
\hline Ceftiofur & 6 & 30.0 & $-2.34^{\mathrm{x}}$ & 0.47 & 0.37 & 0.02 & 2.31 \\
\hline Ampicillin & 6 & 30.0 & $-4.82^{\mathrm{y}}$ & 0.04 & 0.02 & 0.01 & 0.12 \\
\hline Sulfonamides & 4 & 20.0 & & 2.51 & 1.20 & 0.15 & 5.33 \\
\hline
\end{tabular}

${ }^{a}$ Means of intramammary compounds with same superscript did not differ significantly $(P=0.69)$.

${ }^{\mathrm{x}, \mathrm{y}}$ Means of parenteral compounds with same superscript did not differ significantly $(P=0.03)$.

${ }^{1}$ Farms could report the use of multiple products.

${ }^{2}$ For farms reporting usage.

${ }^{3}$ Mean of natural-log transformed DDD per cow per year. Comparison among means was done for compounds used in more than 5 herds.

\section{Treatment of Clinical Mastitis}

Cephapirin was the most frequently used (18 farms) intramammary compound for treatment of clinical mastitis (Table 4). Pirlimycin (15 farms) and amoxicillin (8 farms) were also widely used. Density of use of pirlimycin was associated with the proportion of animals treated for clinical mastitis per year. Farms that were treating a larger proportion of animals for clinical mastitis per year ( $>62 \%$ of total milking cows treated per year) reported using pirlimycin more densely than farms that were treating a smaller proportion of animals per year $(P=0.003$; Figure 1$)$. The usage of the other studied compounds was not associated $(P>0.05)$ with the proportion of animals treated for clinical mastitis.

The majority of CON farms $(\mathrm{n}=14)$ used one or more parenteral antimicrobial drugs (Table 4) to treat about one-third of clinical cases of mastitis (range: 1 to 95\%).

Most organic farmers $(n=19)$ reported the use of organic products for treatment of clinical mastitis but none reported the use of antimicrobial drugs for this purpose. Bovine whey products were the most common (9 farms) treatments. Other products commonly used were garlic tincture, aloe vera, and vitamin $\mathrm{C}$ (Table 5).

The perception of cure after a treatment of clinical mastitis was not significantly associated with farm type $(P=0.52)$. About half of the CON farmers, and onethird of the ORG farmers estimated that less than half of the treated clinical cases of mastitis were cured as a result of treatment. Almost $74 \%$ of ORG farmers using compounds to treat clinical mastitis were satisfied or very satisfied, whereas only $40 \%$ of CON farmers were satisfied or very satisfied with the products used $(P=$ 0.03).

\section{Use of Extralabel and Prohibited Drugs}

Eleven CON producers reported extralabel use of antimicrobial drugs via an intramammary route. Ampicil-

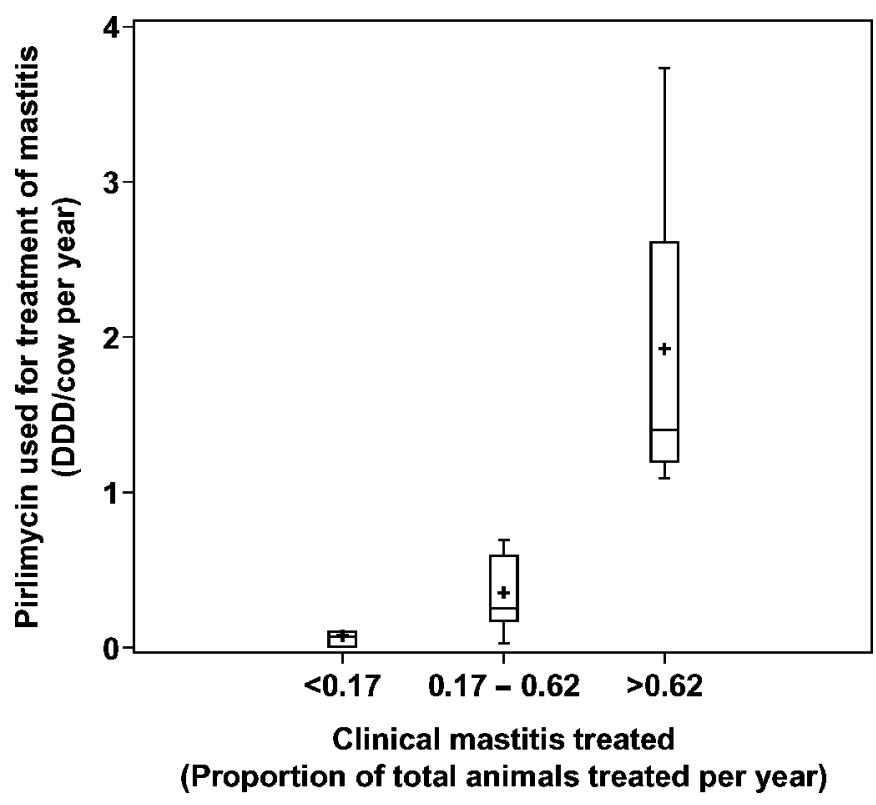

Figure 1. Box plot of density of usage of pirlimycin (defined daily dose/cow per year) used for treatment of clinical mastitis for farms treating different proportions of animals. 
Table 5. Reported products used for treatment clinical mastitis in organic herd $(\mathrm{n}=20)$

\begin{tabular}{|c|c|c|c|}
\hline Product & $\begin{array}{l}\text { Herds with } \\
\text { reported } \\
\text { use, }{ }^{1} \mathrm{n}\end{array}$ & $\%$ & Routes utilized $^{2}$ \\
\hline Whey-based product ${ }^{3}$ & 9 & 45.0 & $\mathrm{PO}, \mathrm{IV}, \mathrm{IM}, \mathrm{SQ}$ \\
\hline Garlic tincture & 7 & 35.0 & $\mathrm{PO}$, in vulva \\
\hline Aloe vera & 6 & 30.0 & PO, IM, IMM, in vulva \\
\hline Vitamin $\mathrm{C}$ & 5 & 25.0 & IM, IMM, IV \\
\hline Aspirin & 4 & 20.0 & $\mathrm{PO}$ \\
\hline Homeopathy & 4 & 20.0 & $\mathrm{PO}$, in vulva \\
\hline Multivitamin supplement ${ }^{4}$ & 4 & 20.0 & $\mathrm{PO}$ \\
\hline Vegetable oils ${ }^{5}$ & 4 & 20.0 & Topical \\
\hline Corticosteroid $^{6}$ & 2 & 10.0 & IM, IMM \\
\hline Electrolytes & 1 & 5.0 & $\mathrm{PO}$ \\
\hline Microbial supplement ${ }^{7}$ & 1 & 5.0 & IMM \\
\hline Vitamin B & 1 & 5.0 & IM \\
\hline
\end{tabular}

lin was used for intramammary treatments on $6 \mathrm{CON}$ farms; ceftiofur and gentamycin were used for intramammary treatments on $3 \mathrm{CON}$ farms each. Two farmers reported the extralabel use of penicillin, 1 producer reported the extralabel use of miconazole, and 1 producer used extralabel oxytetracycline for IMM treatments. Compounds prepared by veterinarians with unknown ingredients were used in 2 farms. Two producers reported use of a prohibited compound for IMM treatments (sulfamethoxazole/trimethoprim). Some products used by organic farmers for intramammary treatment of mastitis (such as aloe vera) are expressly prohibited by the FDA (FDA, 1997).

\section{Other Treatments}

Ceftiofur was the most frequently used compound for treatment of foot infections (13 farms), respiratory disease of adult cows ( 17 farms), and metritis (17 farms) (Table 6). Animals received more DDD of ceftiofur compared with tetracycline (for foot infections and metritis) and ampicillin (for respiratory disease) (Table 6).

Organic farmers utilized a variety of compounds to treat respiratory, uterine, and foot infections. Aloe vera was the most frequently reported treatment (9 farms), and a number of application routes were reported (Table 7).

\section{Overall Usage}

The mean density of usage of the combined antimicrobial drugs used in all CON farms was 5.43 DDD per cow per year (Table 8). The mean density of usage of intramammary compounds (DCT and clinical mastitis) was 3.58 DDD per cow per year, and the IMM route accounted for two-thirds of the total usage, whereas parenteral compounds (injectable, topical, etc.) accounted for the remainder. Intramammary antimicrobial drugs used for treatment of mastitis accounted for $56 \%$ of intramammary usage and for $38 \%$ of the total usage. Parenteral antimicrobial drugs used for the treatment of mastitis accounted for about half of the parenteral usage and $17 \%$ of the total usage (Table 8).

\section{DISCUSSION}

This study was not designed to characterize CON and ORG herds in Wisconsin but to develop a method for assessing usage of antimicrobial drugs in herds that represented a wide variety of usage. The study requirement for comprehensive usage of DCT on CON farms, guaranteed a minimum exposure to IMM antimicrobial drugs for animals housed on CON farms. The use of comprehensive DCT is almost universally adopted by conventional Wisconsin dairy farmers (Rodrigues et al., 2005) and it is likely that this requirement did not result in the enrollment of farms that used more antibiotics than other CON farms. Inclusion criteria for both CON and ORG herds were designed to select farms with a high prevalence of intramammary infections to enhance the ability to recover mastitis pathogens for the second phase of the study (Pol and Ruegg, 2007) and to increase the potential variability in antimicrobial usage (Mitchell et al., 1998). These criteria ap- 
Table 6. Descriptive statistics of defined daily doses (DDD) per cow per year of antimicrobial drugs used for selected diseases of adult cows in conventional herds

\begin{tabular}{|c|c|c|c|c|c|c|c|}
\hline \multirow[b]{2}{*}{ Disease } & \multirow{2}{*}{$\begin{array}{l}\text { Herds with } \\
\text { reported } \\
\text { use, }{ }^{1} \mathrm{n}\end{array}$} & \multirow[b]{2}{*}{$\%$} & \multicolumn{5}{|c|}{ DDD per cow per year ${ }^{2}$} \\
\hline & & & $\begin{array}{l}\text { Mean } \\
\text { LN-DDD }^{3}\end{array}$ & Mean & SE & Minimum & Maximum \\
\hline \multicolumn{8}{|l|}{ Foot infections } \\
\hline Ceftiofur & 13 & 65.0 & $-2.00^{\mathrm{a}}$ & 0.33 & 0.16 & 0.01 & 2.23 \\
\hline Tetracycline & 11 & 55.0 & $-3.95^{\mathrm{b}}$ & 0.05 & 0.02 & 0.00 & 0.19 \\
\hline Penicillin & 5 & 25.0 & & 0.28 & 0.14 & 0.02 & 0.80 \\
\hline Ampicillin & 1 & 5.0 & & 0.02 & & 0.02 & 0.02 \\
\hline \multicolumn{8}{|c|}{ Respiratory infections } \\
\hline Ceftiofur & 17 & 85.0 & $-2.93^{\mathrm{a}}$ & 0.07 & 0.02 & 0.01 & 0.29 \\
\hline Ampicillin & 8 & 40.0 & $-5.57^{\mathrm{b}}$ & 0.01 & 0.00 & 0.00 & 0.03 \\
\hline Tetracycline & 6 & 30.0 & $-3.67^{\mathrm{a}}$ & 0.06 & 0.03 & 0.00 & 0.17 \\
\hline Penicillin & 4 & 20.0 & & 0.10 & 0.04 & 0.02 & 0.18 \\
\hline Sulfonamides & 4 & 20.0 & & 0.05 & 0.03 & 0.01 & 0.16 \\
\hline \multicolumn{8}{|l|}{ Metritis } \\
\hline Ceftiofur & 17 & 85.0 & $-2.01^{\mathrm{a}}$ & 0.19 & 0.04 & 0.01 & 0.52 \\
\hline Tetracycline & 12 & 60.0 & $-3.28^{\mathrm{b}}$ & 0.06 & 0.01 & 0.01 & 0.15 \\
\hline Penicillin & 7 & 35.0 & $-2.23^{\mathrm{a}}$ & 0.14 & 0.05 & 0.04 & 0.46 \\
\hline Ampicillin & 5 & 25.0 & & 0.04 & 0.01 & 0.01 & 0.08 \\
\hline Sulfonamides & 1 & 5.0 & & 0.52 & & 0.52 & 0.52 \\
\hline
\end{tabular}

\footnotetext{
${ }^{\mathrm{a}, \mathrm{b}}$ Means of compounds used in a selected disease with same superscript did not differ significantly $(P>$ $0.05)$.

${ }^{1}$ Farms could report the use of multiple products.

${ }^{2}$ For farms reporting usage.

${ }^{3}$ Mean of natural-log transformed DDD per cow per year. Comparison among means was done for compounds used in more than 5 herds.
}

peared to be successful for enrolling farms that were using a variety of antimicrobial compounds but likely selected for farms that used more intramammary antibiotics as compared with farms with a lower prevalence of subclinical mastitis.

As was observed in other studies (Zwald et al., 2004; Sato et al., 2005a), CON farms were larger and produced more milk than ORG farms. Overall, the mean herd size and milk yield in our study were greater than the state average of 78 cows and $22 \mathrm{~kg}$ (National Agriculture Statistics Service, 2005), probably due to the nonrandom selection of the herds.

In our study, antimicrobial drug usage was determined using a survey that relied on both herd records and recall. The majority of CON and ORG herds ( $\mathrm{n}=$ 16 for both types) reported having treatment records

Table 7. Number of organic herds $(n=20)$ using selected products for treatment of foot infections, metritis, and respiratory infections

\begin{tabular}{|c|c|c|c|c|c|c|c|}
\hline & \multicolumn{2}{|c|}{ Respiratory } & \multicolumn{2}{|c|}{ Metritis } & \multicolumn{2}{|c|}{ Foot } & \multirow[b]{2}{*}{ Routes utilized $^{1}$} \\
\hline & Herds, n & $\%$ & Herds, $\mathrm{n}$ & $\%$ & Herds, $\mathrm{n}$ & $\%$ & \\
\hline Aloe vera & 1 & 5.0 & 7 & 35.0 & 1 & 5.0 & PO, local infusion, \\
\hline Aspirin & 2 & 10.0 & 1 & 5.0 & 1 & 5.0 & $\mathrm{PO}$ \\
\hline Botanic tincture $^{2}$ & & & 4 & 20.0 & & & $\mathrm{SQ}$, infusion \\
\hline Botanic-mineral paste ${ }^{3}$ & & & & & 2 & 10.0 & Local infusion \\
\hline Garlic tincture & 2 & 10.0 & 3 & 15.0 & & & $\mathrm{PO}$, in vulva, infusion \\
\hline Homeopathy & & & 1 & 5.0 & & & $\mathrm{PO}$ \\
\hline Multivitamin/microbial ${ }^{4}$ & 3 & 15.0 & & & & & $\mathrm{PO}$ \\
\hline Nutritional supplement ${ }^{5}$ & & & 2 & 10.0 & & & $\mathrm{PO}$, infusion \\
\hline Vinegar & & & 2 & 10.0 & & & Infusion \\
\hline Vitamin $\mathrm{C}$ & 1 & 5.0 & & & & & $\mathrm{PO}$ \\
\hline
\end{tabular}

${ }^{1}$ Routes: $\mathrm{PO}=$ per os; $\mathrm{SQ}=$ subcutaneous.

${ }^{2}$ Caulophyllum, garlic and golden seal; First Step (Crystal Creek, Inc.).

${ }^{3}$ Mineral oil, diatomaceous earth, sodium bicarbonate, tea tree oil, and eucalyptus oil. (Crystal Creek, Inc.).

${ }^{4}$ Vitamins A, D, E, C, and live lactic acid producing bacteria; Pul-Mate (Crystal Creek, Inc.).

${ }^{5}$ Sodium bicarbonate, garlic, aloe vera; Fresh Cow Bolus (Crystal Creek, Inc.). 
Table 8. Descriptive statistics of estimated defined daily doses (DDD) per cow per year of all reported antimicrobial drugs used for treatment of selected diseases on conventional herds reporting use of each compound by reason to treat and route

\begin{tabular}{|c|c|c|c|c|c|c|c|c|}
\hline & \multirow[b]{2}{*}{ Herds, ${ }^{1} \mathrm{n}$} & \multirow[b]{2}{*}{$\%$} & \multicolumn{4}{|c|}{ DDD per cow per year ${ }^{2}$} & \multirow{2}{*}{$\begin{array}{l}\text { Route }^{3} \\
(\%)\end{array}$} & \multirow{2}{*}{$\begin{array}{l}\text { Total }^{4} \\
(\%)\end{array}$} \\
\hline & & & Mean & $\mathrm{SE}$ & Minimum & Maximum & & \\
\hline \multicolumn{9}{|l|}{ Intramammary } \\
\hline Clinical mastitis & 20 & 100.0 & 2.02 & 0.70 & 0.08 & 11.82 & 56.0 & 38.0 \\
\hline Dry cow therapy & 20 & 100.0 & 1.56 & 0.08 & 1.00 & 2.00 & 43.0 & 28.0 \\
\hline Total intramammary & 20 & 100.0 & 3.58 & 0.74 & 1.21 & 13.77 & 100.0 & 66.0 \\
\hline \multicolumn{9}{|l|}{ Parenteral } \\
\hline Dry cow therapy & 7 & 35.0 & 0.52 & 0.26 & 0.02 & 1.71 & 9.8 & 3.3 \\
\hline Clinical mastitis & 13 & 65.0 & 1.43 & 0.67 & $<0.01$ & 7.83 & 50.3 & 17.1 \\
\hline Foot & 16 & 80.0 & 0.39 & 0.14 & 0.01 & 2.42 & 16.8 & 5.7 \\
\hline Respiratory & 19 & 95.0 & 0.14 & 0.03 & $<0.01$ & 0.61 & 7.4 & 2.5 \\
\hline Metritis & 18 & 90.0 & 0.32 & 0.05 & 0.02 & 0.83 & 15.6 & 5.3 \\
\hline Total parenteral & 20 & 100.0 & 1.85 & 0.51 & 0.05 & 8.59 & 100.0 & 34.0 \\
\hline Total & 20 & 100.0 & 5.43 & 1.06 & 1.43 & 19.93 & 100.0 & 100.0 \\
\hline
\end{tabular}

${ }^{1}$ Farms could report the use of multiple products.

${ }^{2}$ For farms reporting usage.

${ }^{3}$ Percentage of each route represented by reason to treat.

${ }^{4}$ Percentage of the total use of each reason to treat or route.

but all of them also relied on memory to recall the amount and type of compound used. The sole reliance on computerized records or other written records will likely result in serious underestimation of antimicrobial usage on dairy farms. Hoe and Ruegg (2006) recently reported that $66 \%$ of responders from large Wisconsin dairy herds ( $>200$ cows) recorded antimicrobial treatments in computers, in contrast to only $18 \%$ of responders from medium herds (100-200 cows), and only 3 to $4 \%$ of responders from small (50-100 cows) and very small herds ( $<50$ cows). About $3 \%$ of responders from large herds and 15 to $19 \%$ of other herd-size strata indicated that they did not have any records of antibiotic treatments for cows that received antibiotics. Sato et al. (2005b) failed to estimate the amount of antimicrobial drugs used on small farms in Wisconsin because of poor on-farm records. In the absence of widely adopted antibiotic recording systems, information based on recall might be better than computerized records for the type of farms included in the present study.

Mastitis was the most commonly reported disease and the prevalence was similar to previous reports (Erskine et al., 1988; Shpigel et al., 1998; Bartlett et al., 2001). The prevalence of mastitis on ORG farms was less than that reported by CON farmers and similar to previous studies (Vaarst and Enevoldsen, 1997; Sato et al., 2005a). However, a higher incidence in clinical mastitis for ORG herds has also been reported (Sundrum, 2001) and self-reporting of clinical mastitis may be influenced by herd size and herd type. One study reported that farmers converting to organic status in the United Kingdom were less likely to report cases of clinical mastitis (Berry and Hillerton, 2002). Philosophical differences in the detection and perception of cure between ORG and CON farmers were apparent in our study and it is possible that more diseases were noted on CON farms because more treatment options exist. Rodrigues et al. (2005) reported that only half of surveyed Wisconsin dairy herds recorded clinical mastitis but operators of large herds were twice as likely to record cases of mastitis compared with operators of small herds.

Our study detected an association between usage of some antimicrobial drugs and the prevalence of mastitis. Pirlimycin was more commonly used for treatment of clinical mastitis in herds that treat a larger proportion of animals per year. Pirlimycin is one of the few compounds used for treatment of clinical mastitis that has an approved label frequency of one syringe every $24 \mathrm{~h}$ and a relatively short period of milk withholding. These characteristics might be desirable for farmers that are treating a large proportion of their animals.

Density of use of penicillin for DCT was negatively correlated with use of cephapirin used for DCT, mainly reflecting a temporal relationship in the manner of data collection. Farmers tended to use one compound annually, but they often changed compounds from year to year. Results of our survey reflected historical use, because a 5 -yr average was used. Therefore, a farm that used 0.5 DDD of penicillin and 0.5 DDD of cephapirin per cow per year could have been using each compound in all their animals over $2.5 \mathrm{yr}$, or could have been using each compound in half of their animals during the 5yr period. One shortcoming of our study was the inability to discriminate between these 2 situations. For ex- 
ample, novobiocin was used in 3 farms with an average use of 0.22 DDD per cow per year. In one of the farms, novobiocin was given to all cows at dry-off for $1 \mathrm{yr}$. The other 2 farmers used novobiocin in about half of the cows for $4 \mathrm{yr}$, and in a few cows during $5 \mathrm{yr}$, respectively. These different usages resulted in a 5 -yr average of $0.20,0.44$, and 0.02 DDD per cow per year for each of the farms.

Cephapirin and pirlimycin were the most commonly used drugs for treatment of clinical mastitis. Their densities of usage were the greatest among all the compounds and uses studied. Other studies have also reported that $\beta$-lactams are the most common drugs used for treatment of mastitis (Zwald et al., 2004; Sato et al., 2005a; Sawant et al., 2005).

Similar to the results of Zwald et al. (2004), occasional parenteral treatments for mastitis were reported by $70 \%$ of conventional producers. The compounds used are not labeled for treatment of clinical mastitis. Most of the compounds used to treat clinical cases of mastitis have limited distribution in the udder and the efficacy of the compounds has not been well established (Gruet et al., 2001; Taponen et al., 2003). For example, systemic ceftiofur, used by $30 \%$ of the farms of this study to treat clinical cases of mastitis, does not reach effective concentrations in the mammary gland (Owens et al., 1990). However, parenteral use of ceftiofur for treatment of severe cases of coliform mastitis has been reported to be effective in bacteremic conditions (Erskine et al., 2002).

As reported by others (Sundlof et al., 1995; Mitchell et al., 1998), usage of antimicrobial drugs for treatment of mastitis accounted for the majority of total antimicrobial drug usage. However, previous researchers did not quantify the density of use. About $80 \%$ of all antimicrobial drugs used were used for treatment or prevention of mastitis (DCT, 28\%; intramammary compounds for clinical mastitis, $38 \%$; parenteral compound for clinical mastitis, $17 \%$ ). There are a variety of potential reasons for this observation. The farms enrolled in this study were selected to have a high prevalence of IMI and the prevalence of mastitis has been associated with increased use of antimicrobial drugs (Sundlof et al., 1995; Ruegg and Tabone, 2000). Therefore, it is likely that these farms were using more mastitis treatments compared with herds that had better mastitis control programs. Although the specific questions about dosage, frequency, and prevalence of treatments were identical for each of the diseases included in this survey, approximately half of the questions were related to milk quality. Consequently, our estimations of antimicrobial drug usage for treatments of mastitis contained more detail than for other diseases.
Almost half of the ORG herds used some type of product to treat cows at dry-off and nonantimicrobial intramammary products were used for treatment purposes in $25 \%$ of the ORG farms. Zwald et al. (2004) reported that $6 \%$ of the ORG farms used nonantimicrobial intramammary compounds. This difference may be because the present study included more emphasis on treatments given at dry-off. None of the organic herds surveyed by Sato et al. (2005a) or by Zwald et al. (2004) reported the use of antimicrobial drugs at dry-off but one ORG farmer in the present study reported using intramammary antimicrobial drugs given at dry-off in a few cows. Exposure of ORG animals to antimicrobial drugs is probably minimal but cannot be ruled out.

Similar to previous research, ORG farmers did not report using antimicrobial drugs to treat mastitis (Zwald et al., 2004; Sato et al, 2005a). Almost all (95\%) ORG farms used nonantimicrobial compounds for treatment of clinical mastitis. The use of intramammary compounds, including isoflupredone, vitamin $\mathrm{C}$, apple cider, aloe vera, and microbial supplements were reported by 7 farms. The intramammary use of isoflupredone has been shown to be effective in reducing swelling in quarters with induced coliform mastitis but milk production was also reduced (Carroll et al., 1965). The use of vitamin $\mathrm{C}$ for mastitis therapy has not been reported previously, but one study has examined the role of vitamin $\mathrm{C}$ in mammary gland immunity (Weiss et al., 2004). In that study, the concentration of vitamin $\mathrm{C}$ in milk was reduced after inducing mastitis; suggesting therefore, that usage of vitamin $\mathrm{C}$ may have some sort of beneficial effect (Weiss et al., 2004). No studies are available that validate the use of aloe vera, apple cider, or microbial supplements as immunomodulators or as therapeutic agents. The intramammary use of aloe vera is prohibited by the FDA.

A bovine whey product was the most common parenteral product used by ORG producers to treat clinical mastitis and to treat cows at dry-off. The ability of this ultrafiltered whey product to enhance neutrophil activity has been described previously (Roth et al., 2001). The compound affected in vitro neutrophil function, supporting the theory that it may contain cytokines. The use of this ultrafiltered whey product for treatment of clinical mastitis has not been evaluated. Organic producers also reported the use of garlic tincture administered per os or in vulva. The antimicrobial properties of garlic extracts have been reported (Ross et al., 2001). However, garlic tincture has not been evaluated as a therapeutic agent to treat mastitis.

About half (55\%) of CON producers reported extralabel use of intramammary antimicrobial drugs. A valid veterinarian-client-patient relationship (VCPR) is mandatory if extralabel drugs are used. A valid VCPR 
will exist if the veterinarian has assumed the responsibility for treatments, and the client has agreed to follow the instructions of the veterinarian; and when there is sufficient knowledge of the animals by the veterinarian to initiate at least a general or preliminary diagnosis of the disease. Our study did not evaluate the validity of the VCPR, but in 7 of 11 farms using extralabel antimicrobial drugs, producers reported that treatments were based on veterinarians' recommendations. The use of extralabel ceftiofur reported in this study occurred before the release of a commercial intramammary product containing ceftiofur. Extralabel use of ceftiofur has been reported previously (Sawant et al., 2005). Extralabel intramammary use of parenteral preparations of ampicillin was particularly common (30\% of the farms). This practice presents a risk, because there is a possibility of contaminating the preparation; yeast mastitis has been linked to this practice (Gonzalez, 1996). The use of prohibited IMM compounds to treat mastitis was reported by $15 \%$ of the $\mathrm{CON}$ farmers. The survey was not designed to evaluate the density of use of prohibited or extralabel compounds but most of the farmers reported that prohibited compounds were not routinely used and were reserved for treatment of chronic mastitis cases. Only 2 farms provided data necessary to calculate density of use of intramammary penicillin or ceftiofur. The density of use extralabel intramammary penicillin was similar to other intramammary compounds (0.32 DDD per cow per year), however, the density of use of ceftiofur was 17.71 DDD per cow per year. The DDD of ceftiofur was calculated using the recently approved compound dosage $(125 \mathrm{mg} / \mathrm{d})$. Two factors may explain the high density of use: the farm treatment protocol for clinical mastitis was $800 \mathrm{mg}$ of ceftiofur per day for $4 \mathrm{~d}$, and almost $70 \%$ of the herd was treated yearly.

The types of antimicrobial drugs used on dairy farms have been recently reported (Zwald et al., 2004; Kirk et al., 2005; Sawant et al., 2005; USDA/APHIS/VS/CEAH, 2005). These studies reported the proportion of farms using selected antimicrobial drugs. This type of data is relatively easy to collect and if the antimicrobial drug is regularly used it is likely that the farmer would have reported it. The USDA national survey also reported the proportion of animals that were given antimicrobial drugs (USDA/APHIS/VS/CEAH, 2005). These data provide an approximation for density of use, but no data on frequency of treatment or doses were studied. Sundlof et al. (1995) reported results of a mail survey administered to US veterinarians about the use of veterinary drugs. The study used scores based on the reported frequency of use (from daily use to never). This type of data is also an approximation of density of use but the number of farms where the drug was used, the number of the animals treated, and the dose were not collected. None of these studies quantified the amount of antimicrobial drugs used by individual farms, and this topic has not been well described.

One of the objectives of the present study was to quantify antimicrobial drug usage on dairy farms. The data necessary to study the density of antimicrobial drugs usage at farm level include dose, frequency, duration of treatment, and prevalence of treatment. This type of data is difficult to obtain. The collection of this data in our study required a prolonged interview and the use of an extensive questionnaire with picture aids. One of the main difficulties of estimating overall antimicrobial usage is the lack of a standard unit of measurement. The World Health Organization (WHO) Collaborating Center for Drug Statistics Methodology establishes DDD for human drugs (World Health Organization, 2005). Human DDD is defined as an assumed average maintenance dose per day for a drug used for its main indication in adults. The center also develops an Anatomical Therapeutic Chemical (ATC) code for each drug, therapeutic indication, and target organ. The aim of this coupled system is to serve as a tool for standardized drug utilization. This system also allows for time and trend comparisons. At least one review article has focused on the importance of a standard veterinary DDD (Chauvin et al., 2001). The use of a veterinary DDD to describe veterinary antimicrobial usage at the country-level has been described (Grave et al., 1999, 2004; Jensen et al., 2004). To our knowledge, the use of DDD to characterize antimicrobial drug consumption at farm level is a novel approach.

The use of DDD to characterize antimicrobial consumption at the farm level allows for comparisons with other studies that use the farm-level proportion of usage as a unit of measure. However, the DDD approach provides more information. It is possible to calculate the density of use of antimicrobial drugs (number of DDD per cow per year). Because the DDD is a standard unit of measurement, it is possible to compare the exposure to different compounds, used for different purposes, and administered through different routes. Moreover, the DDD permits comparison of compounds expressed with different units (i.e., $\mathrm{mg}$ and IU).

The measurement unit used to characterized antimicrobial in our study usage cannot be directly compared with similar units used in other studies because each is based on a unique pharmacopoeia. Moreover, because the DDD used in this study were based on FDA Center for Veterinary Medicine-approved label dosages, caution should be used when comparing with other studies. In the future, FDA Center for Veterinary Medicine indications may vary resulting in a different DDD state- 
ment and consequently different density of usage estimation.

\section{CONCLUSIONS}

This study describes a novel method for quantifying antimicrobial exposure at the farm-level on dairy farms. A standard measurement unit for evaluation of antimicrobial usage at farm-level was developed. The use of DDD allows comparisons among compounds that are expressed in different units (i.e., $\mathrm{mg}$ and IU) and among different routes. It also allows the estimation of the overall antimicrobial exposure at farm-level. In this study the overall mean exposure to antimicrobial drugs on CON farms was 5.4 DDD per cow per year. Considerable variability among farms was observed, because the minimum overall mean at the farm level was about 1 DDD per cow per year, whereas the maximum was 20 times greater. About two-thirds of the antimicrobial drug doses used at the farm level were intramammary compounds. Penicillin, streptomycin, and cephapirin were the 3 compounds most frequently used for DCT and no differences were observed in their densities of use. Cephapirin, pirlimycin, and amoxicillin were the compounds most frequently used for treatments of clinical mastitis and no differences were observed in their densities of use. Treatment practices for organic herds, including compounds and administration routes were also described.

\section{REFERENCES}

Aarestrup, F. M. 2004. Monitoring of antimicrobial resistance among food animals: Principles and limitations. J. Vet. Med. B Infect. Dis. Vet. Public Health 51:380-388.

Bartlett, P. C., J. F. Aggerb, H. Houec, and L. G. Lawsonb. 2001. Incidence of clinical mastitis in Danish dairy cattle and screening for non-reporting in a passively collected national surveillance system. Prev. Vet. Med. 48:73-83.

Berry, E. A., and J. E. Hillerton. 2002. The effect of selective dry cow treatment on new intramammary infections. J. Dairy Sci. 85:112-121.

Carroll, E. J., O. W. Schalm, and J. Lasmanis. 1965. The use of a synthetic corticoid on experimental coliform (Aerobacter aerogenes) mastitis in cattle: The effects of intramammary and intramuscular administration on the inflammatory response. Am. J. Vet. Res. 26:858-864.

Chauvin, C., F. Madec, D. Guillemot, and P. Sanders. 2001. The crucial question of standardization when measuring drug consumption. Vet. Res. 32:533-543.

Dhar, T., and J. Foltz. 2003. Market structure and consumer valuation in the rBST-free and organic milk markets. Am. Agric. Econ. Assoc. Annu. Mtg., Montreal, Canada. http://www.pats.wisc.edu/ pdfdocuments/marketstructureandvaluation.pdf Accessed 0ct. 23, 2006.

Erskine, R. J., R. J. Eberhart, L. J. Hutchinson, S. B. Spencer, and M. A. Campbell. 1988. Incidence and types of clinical mastitis in dairy herds with high and low somatic cell counts. J. Am. Vet. Med. Assoc. 192:761-765.

Erskine, R. J., P. C. Bartlett, J. L. VanLente, and C. R. Phipps. 2002. Efficacy of systemic ceftiofur as a therapy for severe clinical mastitis in dairy cattle. J. Dairy Sci. 85:2571-2575.
FDA. 1997. Item 15 r. Online: http://www.cfsan.fda.gov/ ear/mi9210a.html Accessed: December 2005.

FDA-Center of Veterinary Medicine. 2005. FDA-approved animal drug products online database system. Online. http:// dil.vetmed.vt.edu/ Accessed Nov. 11, 2005.

Gonzalez, R. N. 1996. Prototheca, Yeast, and Bacillus as a cause of mastitis. Pages 82-92 in Natl. Mastitis Counc. Ann. Mtg. Proc., Nashville, TN. Natl. Mastitis Counc., Inc., Madison, WI.

Grave, K., L. Nilsson, C. Greko, T. Mørk, O. Odensvik, and M. Rłnning. 1999. The usage in Norway and Sweden of veterinary antibacterial drugs for mastitis during 1990-1997. Prev. Vet. Med. 42:45-55.

Grave, K., M. Kaldhusdalc, H. Krused, L. M. Fevang Harre, and K. Flatlandsmof. 2004. What has happened in Norway after the ban of avoparcin? Consumption of antimicrobials by poultry. Prev. Vet. Med. 62:59-72.

Gruet, P., P. Maincentb, X. Berthelotc, and V. Kaltsatosa. 2001. Bovine mastitis and intramammary drug delivery: Review and perspectives. Adv. Drug Deliv. Rev. 50:245-259.

Hoe F. G. H. and P. L. Ruegg. 2006. Opinions and practices of Wisconsin dairy producers about biosecurity and animal wellbeing. J. Dairy Sci. 89:2297-2308.

Jensen, V. F., E. Jacobsen, and F. Bager. 2004. Veterinary antimicrobial-usage statistics based on standardized measures of dosage. Prev. Vet. Med. 64:201-215.

Kirk, J. H., B. McCowan, E. R. Atwill, K. S. Glenn, G. E. Higginbotham, C. A. Collar, A. Castillo, B. A. Reed, N. G. Peterson, and J. S. Cullor. 2005. Association of minimum inhibitory concentration cluster patterns with dairy management practices for environmental bacteria isolated from bulk tank milk. J. Dairy Sci. 88:3710-3720.

McEwen, S. A., and P. J. Fedorka-Cray. 2002. Antimicrobial use and resistance in animals. Clin. Infect. Dis. 34:S93-S106.

Merck Veterinary Manual. 2005. Online: http://www.merck vetmanual.com/mvm/index.jsp Accessed Nov. 15, 2005.

Mitchell, J. M., M. W. Griffiths, S. A. McEwen, W. B. McNab, and A. J. Yee. 1998. Antimicrobial drug residues in milk and meat: Causes, concerns, prevalence, regulations, tests, and test performance. J. Food Prot. 61:742-756.

National Agriculture Statistics Service. 2005. Online: http://www. usda.gov/nass/sso-rpts.htm Accessed Nov. 15, 2005.

Owens, W. E., Z. Y. Xiang, and C. H. Ray. 1990. Determination of milk and mammary tissue concentrations of ceftiofur after intramammary and intramuscular therapy. J. Dairy Sci. 73:3449-3456.

Phillips, I., M. Casewell, and T. Cox. 2004. Does the use of antibiotics in food animals pose a risk to human health? A critical review of published data. J. Antimicrob. Chemother. 53:28-52.

Pol, M., and P. L. Ruegg. 2007. Relationship between antimicrobial drug usage and antimicrobial susceptibility of gram-positive mastitis pathogens. J. Dairy Sci. 90:262-273.

Rodrigues, A. C. O., D. Z. Caraviello, and P. L. Ruegg. 2005. Management of Wisconsin dairy herds enrolled in milk quality teams. J. Dairy Sci. 88:2660-2671.

Ross, Z. M., E. A. O'Gara, D. J. Hill, H. V. Sleightholme, and D. J. Maslin. 2001. Antimicrobial properties of garlic oil against human enteric bacteria: Evaluation of methodologies and comparisons with garlic oil sulfides and garlic powder. Appl. Environ. Microbiol. 67:475-480.

Roth, J. A., D. E. Frank, P. Weighner, and M. Weighner. 2001. Enhancement of neutrophil function by ultrafiltered bovine whey. J. Dairy Sci. 84:824-829.

Ruegg, P. L., and T. J. Tabone. 2000. The relationship between antibiotic residue violations and somatic cell counts in Wisconsin dairy herds. J. Dairy Sci. 83:2805-2809.

SAS Institute. 1999. SAS/STAT User's Guide. Version 8.02 SAS Inst., Inc., Cary, NC.

Sato, K., P. C. Bartlett, R. J. Erskine, and J. B. Kaneene. 2005a. A comparison of production and management between Wisconsin organic and conventional dairy herds. Livest. Prod. Sci. 93:105-115. 
Sato, K., P. C. Bartlett, and M. A. Saeed. 2005b. Antimicrobial susceptibility of Escherichia coli isolates from dairy farms using organic versus conventional production methods. J. Am. Vet. Med. Assoc. 226:589-594.

Sawant, A. A., L. M. Sordillo, and B. M. Jayarao. 2005. A survey on antibiotic usage in dairy herds in Pennsylvania. J. Dairy Sci. 88:2991-2999

Shpigel, N. Y., M. Winkler, G. Ziv, and A. Saran. 1998. Clinical, bacteriological and epidemiological aspects of clinical mastitis in Israeli dairy herds. Prev. Vet. Med. 35:1-9.

Sundlof, S. F., J. B. Kaneene, and R. Miller. 1995. National survey on veterinarian-initiated drug use in lactating dairy cows. J. Am. Vet. Med. Assoc. 207:347-352.

Sundrum, A. 2001. Organic livestock farming: A critical review. Livest. Prod. Sci. 67:207-215.

Taponen, S., A. Jantunen, E. Pyorala, and S. Pyorala. 2003. Efficacy of targeted 5-day combined parenteral and intramammary treatment of clinical mastitis caused by penicillin-susceptible or penicillin-resistant Staphylococcus aureus. Acta Vet. Scand. 44:53-62.
USDA National Organic Program. 2002. Organic production and handling standards. 2002. Online: http://www.ams.usda.gov/nop/ FactSheets/ProdHandE.html Accessed Oct. 15, 2005.

USDA APHIS:VS:CEAH. 2005. Part IV: Antimicrobial use on U.S. dairy operations, 2002. Online: http://www.aphis.usda.gov/vs/ ceah/ncahs/nahms/dairy/index.htm\#dairy02 Accessed Jan. 15, 2006.

Vaarst, M., and C. Enevoldsen. 1997. Patterns of clinical mastitis manifestations in Danish organic dairy herds. J. Dairy Res. 64:23-37.

Weiss, W. P., J. S. Hogan, and K. L. Smith. 2004. Changes in vitamin $\mathrm{C}$ concentrations in plasma and milk from dairy cows after an intramammary infusion of Escherichia coli. J. Dairy Sci. $87: 32-37$.

World Health Organization. 2005. Collaborating Center for Drug Statistics Methodology. Online. http://www.whocc.no/atcddd/ Accessed Nov. 11, 2005.

Zwald, A. G., P. L. Ruegg, J. B. Kaneene, L. D. Warnick, S. J. Wells, C. Fossler, and L. W. Halbert. 2004. Management practices and reported antimicrobial usage on conventional and organic dairy farms. J. Dairy Sci. 87:191-201. 